\title{
INTERNATIONAL IMPLICATIONS OF GERMAN UNIFICATION
}

\author{
Hans-Werner Sinn
}

This paper was prepared for the 52nd IIPF Congress in Tel Aviv, Israel, August 26-29, 1996. The author gratefully acknowledges careful research assistance and useful comments by Helge Berger, Holger Feist, Ronnie Schöb, Ulrich Scholten, Claudio Thum, and Alfons Weichenrieder.

(C) 1996 by Hans-Werner Sinn. All rights reserved. Short sections of text, not to exceed two paragraphs, may be quoted without explicit permission provided that full credit, including (C) notice, is given to the source. 


\title{
INTERNATIONAL IMPLICATIONS OF GERMAN UNIFICATION
}

\section{ABSTRACT}

This paper advances the hypothesis that the EUS crisis was caused by German unification. The unification has implied a massive resource demand which parallels the US resource demand following Reagan's tax reforms in the eighties. The resource demand revised the German interest rates relative to the rest of the world which brought about devaluations of other European currencies. The paper identifies those European currencies which currently are undervalued.

\author{
Hans-Werner Sinn \\ Center for Economic Studies \\ Department of Economics \\ University of Munich \\ 80539 Munich \\ Germany
}




\section{Introduction}

The unification of Germany has not only been an internal affair. It has also accelerated the unification of Europe as a whole, and its economic consequences have severely affected the rest of Europe if not the rest of the world.

The acceleration of European unification has occurred because of the widely held belief that only a tight integration of Germany into the European Community would make it possible to control and influence the economic power center thought to have been created by German unification. Nicholas Ridley, the British Secretary of Commerce who had publicly expressed the opposite view that European integration was a German trick aimed at controlling the rest of Europe, had to resign immediately after making his statement. The official policy of Europe's governments was for, not against, a tighter integration of Germany.

The unification of Germany has also had a very direct effect on the Maastricht treaty. When Chancellor Kohl and President Mitterand announced in early 1990 that there would be a government conference in Maastricht, Mitterand also promised his support for the unification of Germany. This was a surprising step, given that in late 1989 Mitterand had tried his utmost to prevent that unification. He had tried hard to stabilise the east German regime and to persuade Gorbachev to veto the unification, but without success. It is an open secret that Germany had to buy the consent of France by sacrificing the deutschmark.

Ironically, the ease with which the unification of Germany has swept away the political barriers to a currency union contrasts sharply with the economic obstacles unification created for such a union. The economic unification of Germany has probably been the largest shock to the world economy since Reagan's tax reform in 1981. Germany is currently soaking up resources from all over the world to feed the east Germans who are still a long way from earning their own living and the German currency is strongly overvalued relative to a long run equilibrium. Freezing the current exchange rate through a currency unification may create severe problems for Germany and its trading partners when the unification shock has been overcome and east Germany has become a well-functioning economy, which it certainly will in the foreseeable future. 
This paper describes how Germany and its trading partners were affected by the events, compares the German unification shock with the shock created by Reagan's policies and analyses its impact on interest and exchange rates and on the performance of the European Monetary System (EMS). An attempt is made to determine which currencies have survived the German unification shock in a condition sufficiently good for entry into a currency union, and which currencies need a realignment before entering. The paper also analyses the kinds of problems which would arise if these currencies entered without a realignment, and it comments on the widely held belief that a European currency union would cause problems similar to those caused by the German currency union.

The paper cannot claim full originality, because much has been said about the German unification, Europe and the exchange markets in the literature. The basic point, that the revaluation of the deutschmark was caused by German unification, has been made by various authors $^{1}$, and there have even been allusions to Reagan's tax reforms in this context by Branson (1993, 1994) and Sinn \& Sinn (1992, 44-51, esp. p. 51). However, the issue seems sufficiently important to justify a synthesis and broader analysis using the statistical information available in 1996. This is particularly so as the realisation of the Maastricht treaty comes nearer and the decision about the countries joining the union will have to be made soon.

\section{Thirsty as a Giant}

Although Germany is the biggest country of the European Community, with one quarter of its population, it is not a giant. Russia's population is $80 \%$ larger, Turkey will have reached Germany's size within a decade, and China is as big as almost 15 Germanies. However Germany is as thirsty as a giant, because east Germany absorbs far more resources than it produces.

Figure 1 shows the development of east German absorption since the unification occurred. Absorption has more than doubled in the six years that have elapsed, and currently it is still about $50 \%$ larger than the east German GDP. In 1996 the east German economy absorbs DM 235 billion more in terms of consumption, investment and public expenditure on

\footnotetext{
${ }^{1}$ Cf., e.g., Issing (1992), Svensson (1994) or Deutsche Bundesbank, Monatsbericht, Mai 1996, S. 55.
} 
goods and services than it produces. About one third of the excess absorption stems from private capital imports into the east German economy and two thirds are public transfers, primarily for unemployment benefits, pensions and public infrastructure investment. The total amount of public funds that has been pumped into the east German economy in the first six years since unification approximates DM 800 billion. This sum excludes the deficit of the Treuhandanstalt, the government controlled resolution trust for the industries of the old Länder. If the Treuhand deficit is added, the total sum of public resource transfers increases to about DM 1000 billion.

Figure 1: Excess absorption in the new Länder and its financing

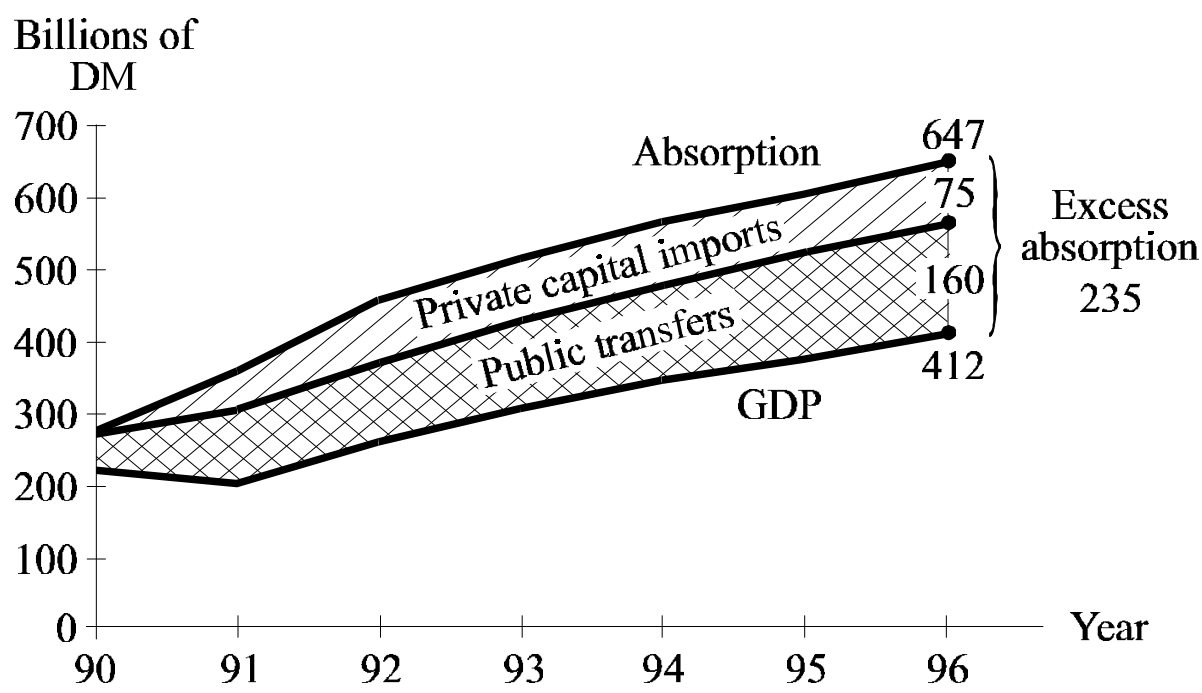

Source: Bundesbank, Monatsbericht, July 1995, Frankfurt/Main, p. 48. Deutsches Institut für Wirtschaftsforschung, DIW Wochenbericht, 27-28/95, 30/95, and 42-43/95, Berlin 1995, pp. 464, 524, and 734. Statistisches Bundesamt, Fachserie 18, Reihe 1.2, Konten und Standardtabellen, Vorbericht 1995, Wiesbaden, p.76.

Notes: The new Länder's nominal gross domestic product is augmented by net imports to calculate absorption. Net imports include not only the trade deficit with foreign countries, but also with the old Länder (former Federal Republic of Germany). It therefore can be interpreted as the excess absorption of the new Länder. Net public transfers are measured as the sum of the transfers to the new Länder made by central and local governments and include special subsidy programs and social insurance. The deficit of the Treuhandanstalt is not included. The transfers are measured net of taxes and fees from the new Länder. The residual of excess absorption and public transfers is private capital imports (and private transfers). The data for 1995 are preliminary, those for 1996 are estimates.

The sums are truly large, especially if they are compared with the capital imports of other eastern countries. From 1990 through 1995 the accumulated net inflow of capital into all 
other former Comecon countries amounted to no more than DM 115 billion $^{2}$ and the accumulated inflow of direct investment was only about DM 60 billion. ${ }^{3}$ In 1995 the net per capita import of resources into east Germany was more than 160 times the per capita import of resources into all other former eastern bloc countries, and by 1995 direct investment per capita was about one hundred times as large in east Germany as in the other eastern European countries. $^{4}$

The public transfers which explain two thirds of east Germany's excess absorption reflect Germany's current problems. East Germans were promised the west German living standard, but the naive belief that this promise could be kept by simply raising east German wages to the western level has virtually led to the destruction of the east German manufacturing industry. Four out of five jobs that were available in manufacturing before unification have disappeared without being replaced. Manufacturing output has declined by two thirds and is recouping only gradually. Union wages are now basically at the west German level, but unemployment benefits, social aid and public pensions are the expensive consequence for the German government budget.

Most of the public funds have been borrowed by the German government. Chancellor Kohl had made something like President Bush's "read my lips" promise in 1990, excluding tax increases as a means of financing unification. As a consequence, there have been no major tax increases in Germany since the time of unification. On the contrary, in 1993 the so-called "location preservation law" (Standortsicherungsgesetz) was passed and this implied a substantial reduction of business taxes. As a result of the divergence between public expenditure and revenue, the German public debt jumped from DM 928.8 billion in 1989 to DM 1994.5 billion by the end of 1995 . The ratio of debt to GDP has climbed from $41.8 \%$ to

\footnotetext{
${ }^{2}$ Estimation based on European Bank for Reconstruction and Development, Transition Report 1995, London, Annex 11.1, and European Bank for Reconstruction and Development, Transition Report Update, London, April 1996. For some smaller eastern economies the data for 1990 and 1991 are not available.

${ }^{3}$ UN/ECE, East-West Investment News, Summer 1996 (2). European Bank for Reconstruction and Development, Transition report 1994, London p. 123. The foreign direct investment figure excludes Armenia, Azerbaijan, Georgia, Kyrgyzstan, Tajkistan, Turkmenistan and Uzbekistan. Note that 1995 data are not yet complete for all countries.

${ }^{4}$ The "net import of resources" is the current account deficit and direct investment is greenfield investment plus foreign acquisitions. For the purpose of this comparison, east Germany is treated like a separate country; i.e., the imports include those from west Germany. Sources: DIW-Wochenbericht 3/95, table 1; Jahresabschluß der Treuhandanstalt (31 December 1994); UN/ECE, Statistical Survey of Recent Trends in Foreign Investment in East European Countries, November 1995, p.72. Cf. also Sinn and Weichenrieder (1996).
} 
$57.7 \%$. By the end of 1996 , the ratio will have grown to $61 \%$, violating even the Maastricht criterion.

Figure 2: The German debt-GDP ratio

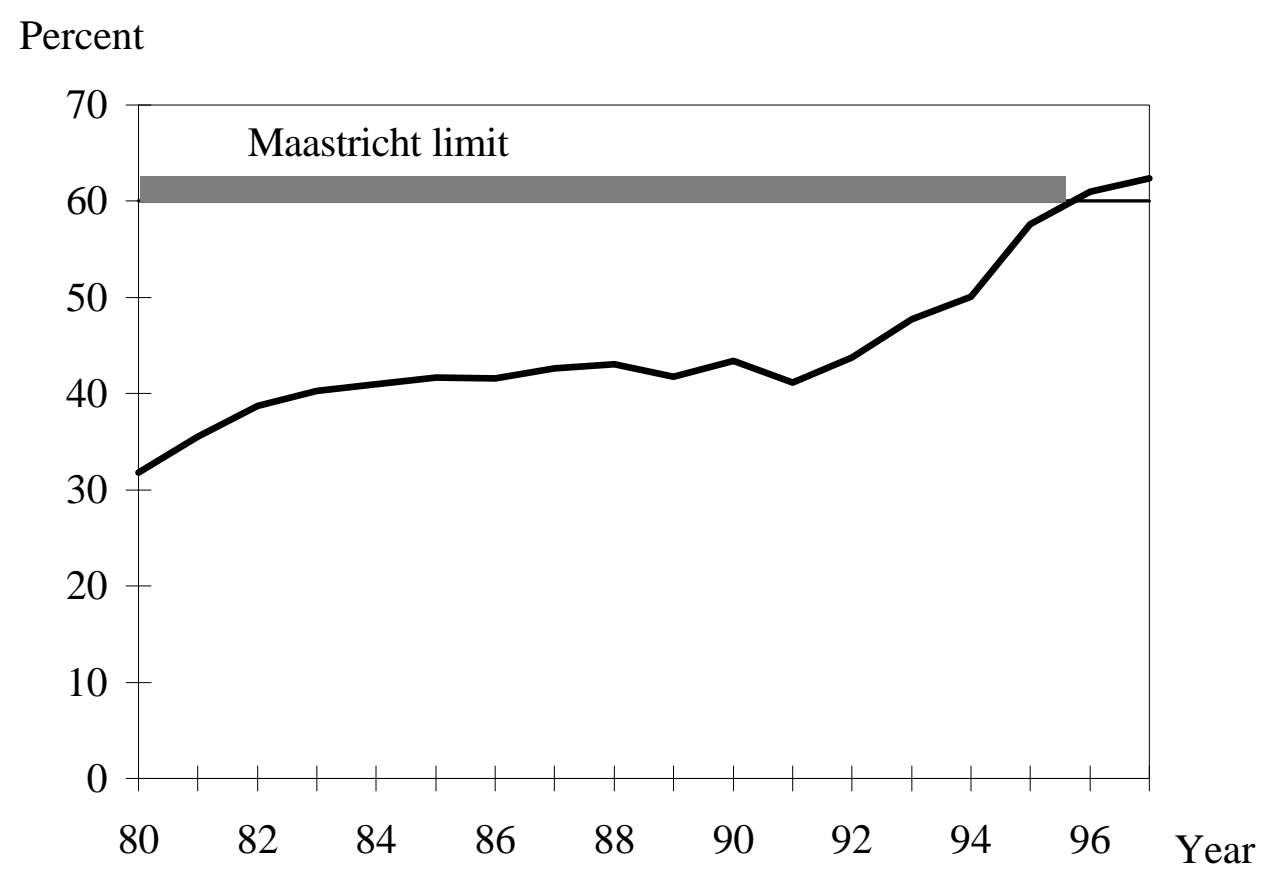

Sources: Bundesbank (various issues), Monatsbericht, Frankfurt/Main, Table "Verschuldung der öffentlichen Hand"; Statistisches Bundesamt (various issues), Statistisches Jahrbuch, Tables "Volkswirtschaftliche Gesamtrechnung"; OECD Economic Outlook 59, Annex of Table 61.

Notes: The graph shows the debt-GDP ratio for Germany's public sector. Treuhand debt is included starting in 1995. 1996 and 1997 are OECD projections.

The public and private resources which Germany needed for its new Länder could, in principle, have been financed by belt tightening; i.e., with increased private savings. However, this did not happen. German households obviously knew little about Ricardian equivalence and did not react to the foreseeable future tax burden which the public borrowing is likely to encounter by curtailing their consumption levels. ${ }^{5}$

So, the necessary resources in fact had to come from abroad. In 1989, Germany had a current account surplus of DM 107 billion which was then the largest current account surplus

\footnotetext{
${ }^{5}$ They may also have been Ricardians with more sophisticated expectations. For example, they may have expected that the service of public debt will be financed with public expenditure cuts rather than tax increases or they may have expected an increase in the future value added tax and thus substituted away from expensive future consumption to cheap present consumption.
} 
in the world. ${ }^{6}$ As Figure 3 shows, with the unification this situation changed rapidly. From 1991 onwards the current account has been persistently negative and Germany has turned into a capital importing country. The change in the current account relative to the year 1989 was about DM 160 billion, which just happens to equal the amount of the current flow of public funds from west to east Germany.

Figure 3: The squeeze on the current account balance

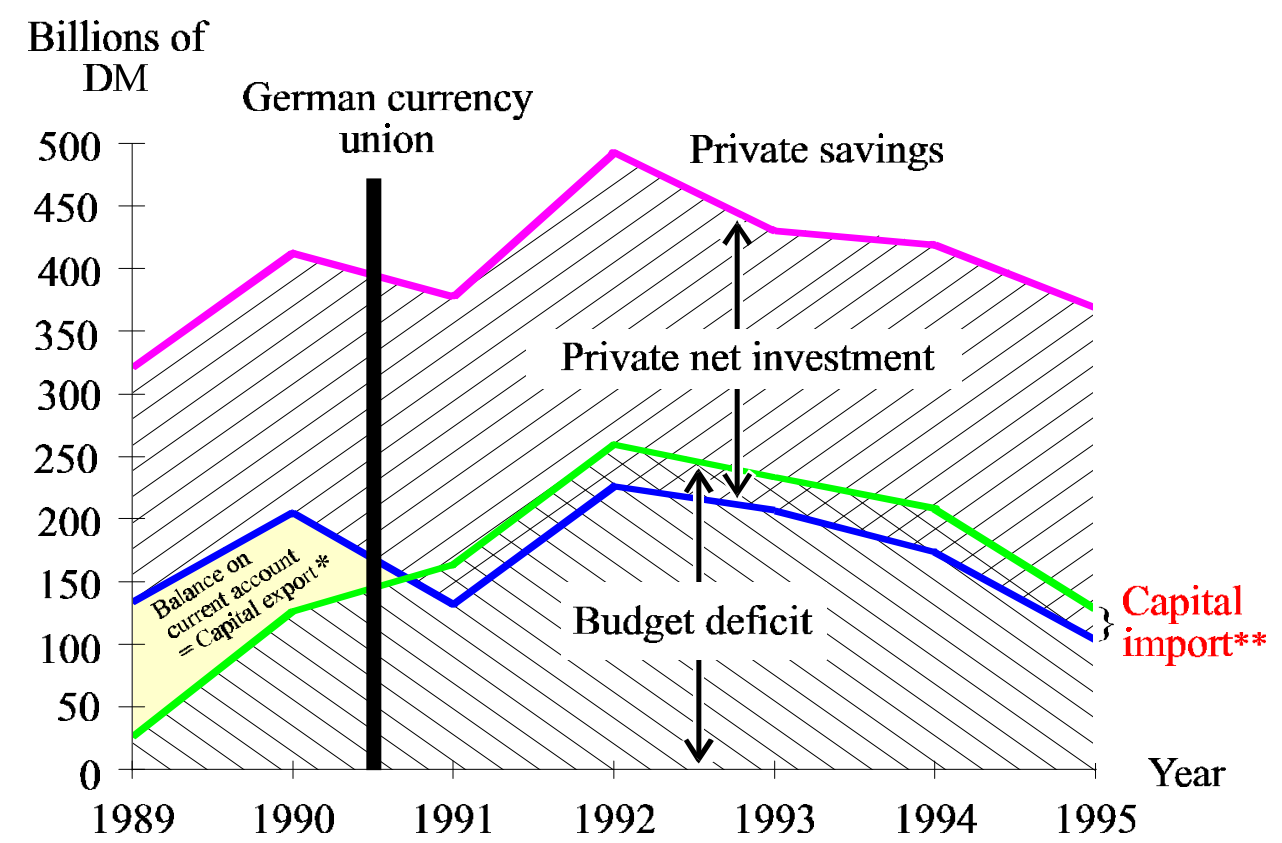

*Plus transfers to other countries. **Minus transfers to other countries.

Sources: Bundesbank (various issues), Monatsbericht, Frankfurt/Main; Statistisches Bundesamt (various issues), Volkswirtschaftliche Gesamtrechnung, Fachserie 18, Reihe 3; Deutsches Institut für Wirtschaftsforschung, DIW Wochenbericht, 46/91, 34/92, 46/94, 7/96, Berlin; Treuhandanstalt, various press releases; information from Bundesanstalt für vereinigungsbedingte Sonderaufgaben of 19.7. 96.

Notes: The government budget deficit includes the borrowing for the German Unity Fund and the deficit of the GDR budget. Until 1994 the government budget deficit included the net borrowing and the sales proceeds of the Treuhandanstalt. The debt of the Treuhandanstalt was transferred to the Erblastentilgungsfond in 1995. The 1995 figure hence includes the change in the net debt of the Erblastentilgungsfond.

The resources which Germany needed came primarily from the other EC countries which are Germany's major trading partners. In 1991 they financed two thirds of the current account deficit and in 1995 nearly all of it. Figure 4 illustrates the situation.

${ }^{6}$ One third of this surplus (DM 36.9 billion) consisted of voluntary transfers to other countries, two thirds of net capital exports. 
Figure 4: Germany's current account, the EC and the rest of the world

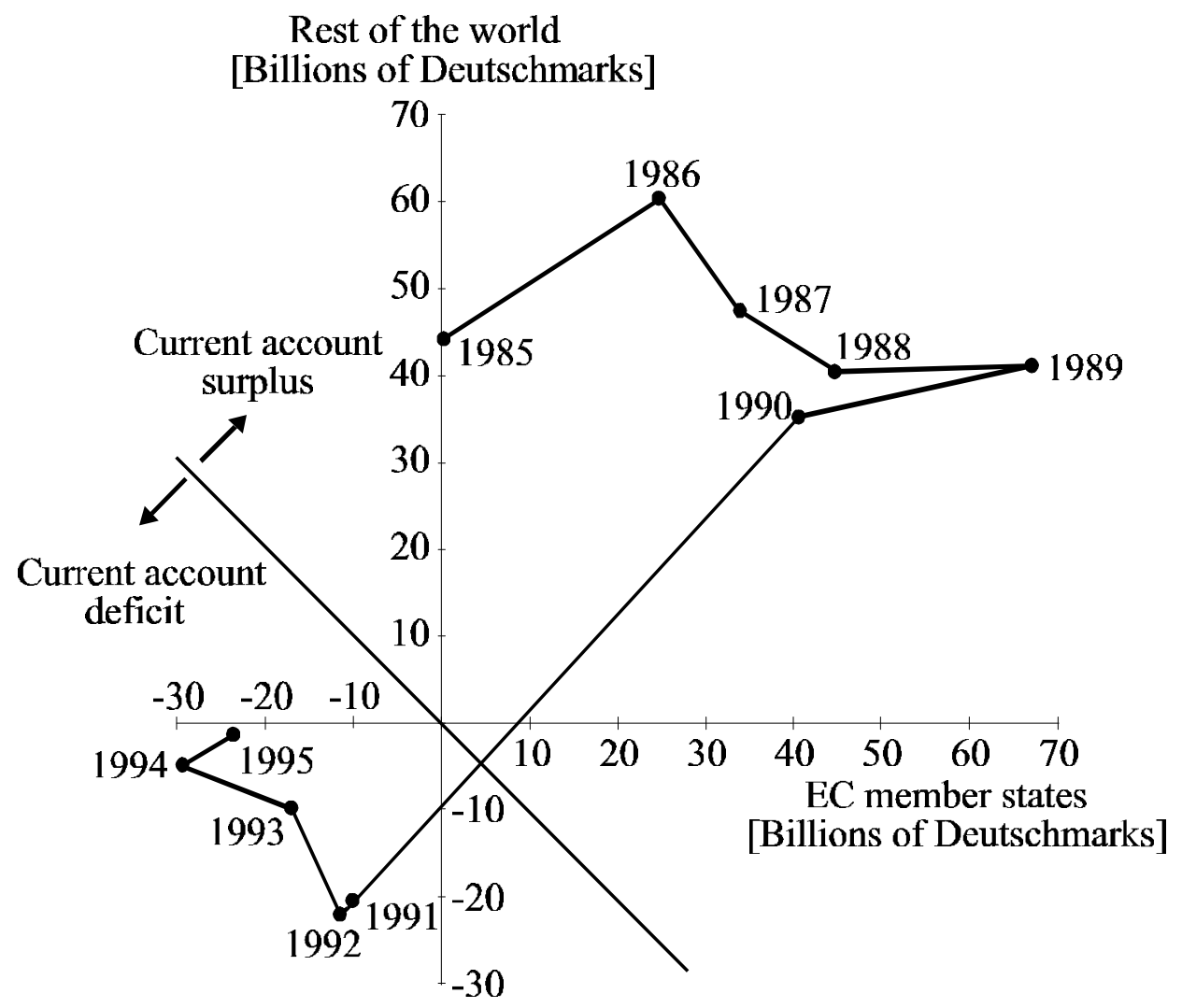

Source: Bundesbank, Zahlungsbilanzstatistik, table "Leistungsbilanz nach Ländern und Ländergruppen", various volumes, Frankfurt/Main.

Note: The graph shows Germany's current account surplus against all states that joined the EC up to the end of 1994 and against all other countries. The sum of the balances defines Germany's whole current account surplus. The downward sloping curve which leads through the origin has a slope of -1 . Points on this curve are characterized by a German current account surplus of zero.

Despite being a net importer of resources, Germany has a positive current account with some countries, in particular with the United States. In 1995 Germany's current account surplus with the US was about DM 17 billion. The United States, too, has been in a particular situation which has required a substantial amount of resource absorption, and there are, in fact startling similarities with the German unification. To understand the situation of the US we need to look back to the year 1981 . 


\section{Reagans's Tax Reforms: A Historically Similar Experiment}

In 1981, President Reagan had persuaded the US parliament to pass a tax reform which may well have been the most radical in US history. Despite the occasional hope for a Laffer curve effect, the tax cuts associated with the reform brought about a rapid increase in the US federal budget deficit which, accumulated over a period of five years, was estimated to amount to some $\$ 160$ billion. $^{7}$

Even more important than the budget effects may have been the incentive effects of the so-called Accelerated Cost Recovery System (ACRS) which was the most important part of the reform package. The ACRS implied a dramatic shortening of the write-off periods for investment projects and provided a massive investment stimulus. Combined with the investment tax credit, the stimulus was approximately equal to an immediate write-off. With tax rates in the neighborhood of $50 \%$, as they were at the time, the switch from economic depreciation to an immediate write-off implies that investment projects can survive a doubling of the rate of interest without becoming unprofitable. In other words, the investment demand curve shifts upward to twice its original level. The reform actually carried out did not quite have such a dramatic effect because some acceleration of tax depreciation had been previously allowed. Nevertheless, it was estimated in Sinn (1984) that the long-run cumulative effect of the ACRS on US capital imports would have been about \$ 1000-1500 billion. Reagan's tax reforms of 1981 have partly reversed by the subsequent reforms of 1986, but they have had a long-lasting effect on the trade relationship between the US and the rest of the world. ${ }^{8}$

US interest rates rose sharply after the recession of 1982 and reached a historical peak in 1994. The implication was that the dollar became a very attractive investment currency and climbed to a peak value of DM 3.45 in February 1985. The US current account, which before the reform had been balanced, turned strongly negative. In the first five years after the reform, the accumulated capital import of the United States was \$ 390 billion more than in the last five

\footnotetext{
${ }^{7}$ See Sinn (1984).

${ }^{8}$ A comparison of the 1981 and 1986 reforms can be found in Sinn (1988).
} 
years before the reform, and, by the end of 1995, it had increased to $\$ 1320$ billion, about what had been predicted.

Undoubtedly, the US tax reform was a major shock to the world economy. The shock waves were felt everywhere. While foreign exporters were happy about the business they could make with a high value of the dollar, debtors all over the world were running into problems because they had to pay higher interest rates. In Europe the building industries collapsed, and, in all likelihood, even the world debt crisis was triggered off by the rising interest rates. ${ }^{9}$

The resource demand which the German unification produced for the world economy was not very different from that created by Reagan's tax reforms. Despite the fact that the events had their own idiosyncratic causes, the common elements were the sharp increase in the public budget deficit and a special stimulus for private investment. In the US, this stimulus came from the ACRS, in Germany it came from the new investment opportunities in the new Länder.

Surprisingly, even the magnitudes of the resource demands for the two events were rather similar. In the first five years after German unification, the accumulated effect on the German current account has amounted to a differential capital import of $\$ 338$ billion relative to the last five years before unification. This is the same order of magnitude as the $\$ 390$ billion which measure the accumulated impact of Reagan's reforms in the succeeding five years. Figure 5 illustrates the striking similarity in the magnitudes of US and German capital imports following the two different historical events.

\footnotetext{
${ }^{9}$ During the seventies the developing countries had been able to borrow at negative real rates of interest. After the US tax reform, the real rates jumped by 5 percentage points to a level of about 4 percent which many developing countries were unable to bear. Starting with Mexico in 1982, many of them declared their inability to service their debts. See Sinn (1993) for details.
} 
Figure 5: Net resource imports following Reagan's tax reforms and German unification

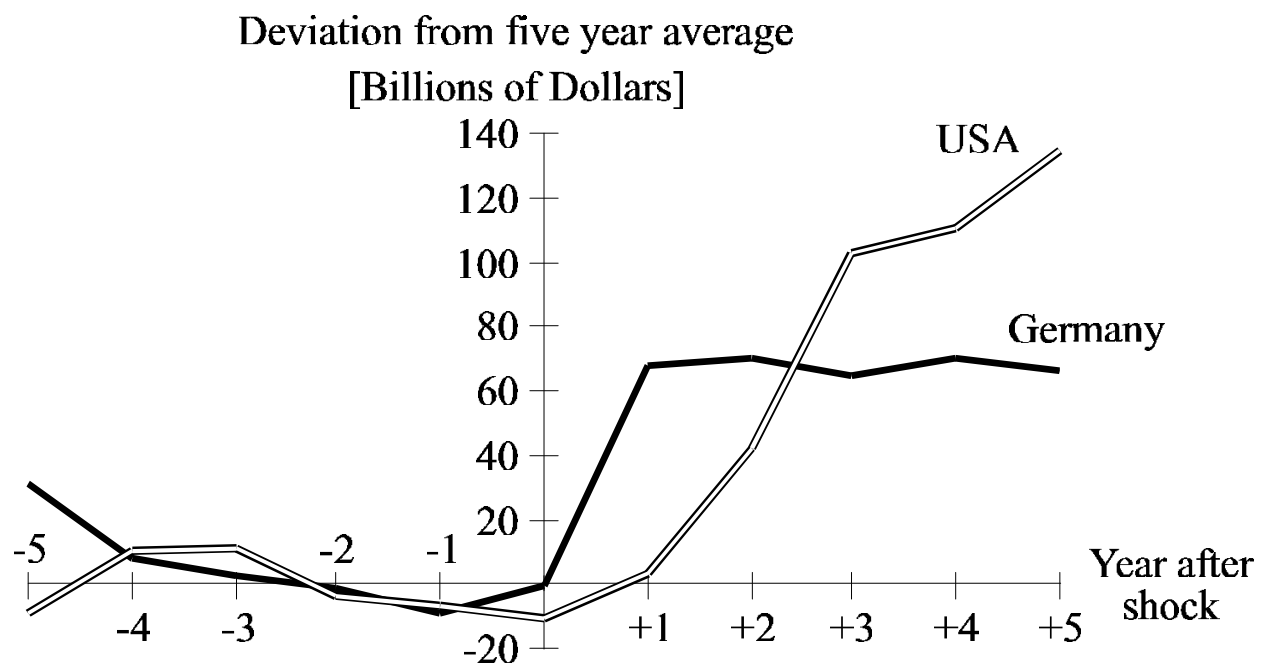

Sources: OECD, Main Economic Indicators, Historical Statistics, 1969-1988, 1990, p. 91, OECD, Economic Outlook, July 1996, pp. A 40 and A 53.

Note: The additional net resource import after the shocks has been calculated from current account data. The curves have been adjusted so that the average in the last five years before the shock is zero. In the US, the shock was in 1981, in Germany, the shock was in 1990.

\section{The Revaluation of the Deutschmark and the European Currency Crisis}

The unification of Germany, too, was a shock, and it also produced a crisis. Not a world debt crisis but a crisis for the European Monetary System. The high public and private demand for capital increased German interest rates relative to those in other countries, increased the deutschmark's attractiveness as an investment currency and created strong appreciation pressure. Initially, the EMS prevented the deutschmark from appreciating after unification. Despite the Bundesbank's offer to revalue the deutschmark within the system, a political decision was made to defend the existing exchange rates. However, the EMS was only temporarily able to prevent the flood of capital that had been attracted. Economic forces were stronger than political will. Only two years after unification, the EMS broke down and the deutschmark became free to revalue.

The following figures show what happened. Figure 6 shows the development of the German interest rates and those in the other EMS countries. Before unification, there had been a persistent interest differential between Germany and the other EMS countries of 400 base 
points and more. This differential shrank rapidly after unification. The high demand for funds in the German capital market which resulted from the boom brought about by unification created a textbook-like response by the interest rates.

Figure 6: Daily interest rates: Germany vs. EMS

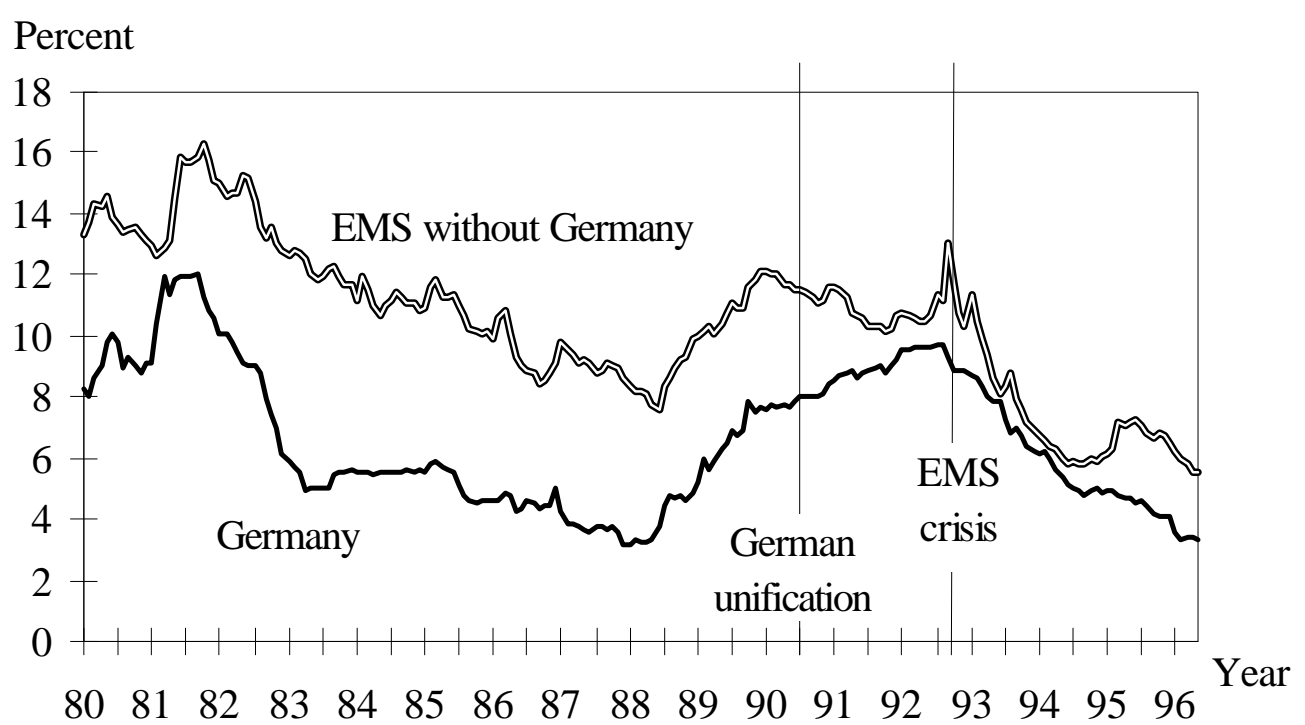

Sources: Bundesbank (various issues), Monatsbericht, Frankfurt/Main, Tables IV.4; letter from Bundesbank of July 11, 1996; OECD, National Accounts, Paris 1996, Table 3, p. 158; own calculations.

Notes: The broken curve shows the weighted daily interest rates of the EMS countries without Germany. Weights are based on 1980 GDP figures. EMS countries include Austria, Belgium, Denmark, Spain, France, Italy, Ireland, Netherlands, Portugal, and the UK. Due to a lack of data, some country series start later than 1980. Weights have been adjusted accordingly.

The interest response was not limited to short term rates or to European currencies. Fig. 7 shows the development of German long term rates compared to the long term rates in the US and in western Europe's biggest countries. The picture is always the same. Unification pulled the traditionally low German interest rates upwards against the rates in other countries. The figure shows that German and US interest rates in particular have coincided closely since unification. In the eighties, the unusual circumstances in the US explained an American interest lead of more than 200 base points. In the nineties the unusual circumstances in Germany and the US have balanced out. The long term interest rates are more or less the same. 


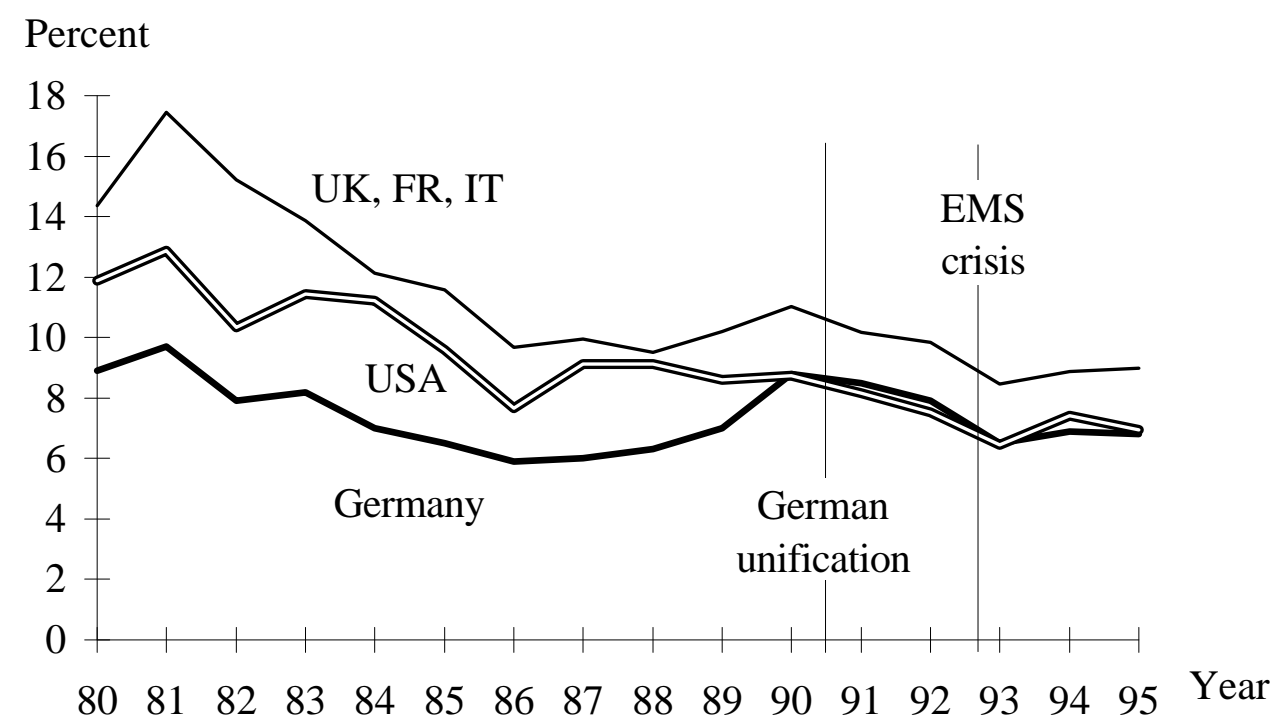

Sources: OECD (various issues), Main Economic Indicators, Paris.

Notes: The series UK, FR, IT is the unweighted mean of the respective country interest rates.

There is only one important exception to the general trend of a shrinking interest differential - the EMS crisis itself. In the second half of 1992 various European central banks made desperate attempts to defend their currencies against devaluations by artificially increasing the short term interest rates. Figure 8 shows this for Sweden and Ireland. Sweden was not a member of the EMS, but had unilaterally tried to peg the krone to the EMS. Ireland was a member. In both countries the daily interest rates were pushed to astronomical heights. Since the figure shows the monthly averages of the daily interest rates, it understates the actual development. On September 17th the Swedish discount rate was $500 \%$.

The temporary increase in the short term interest rates is an exception to the post unification trend and it indicates how strong the market forces must have been. Both Sweden and Ireland lost the game. Like so many other currencies, their currencies were devalued relative to the deutschmark 
Figure 8: Desperate attempts to defend the exchange rate

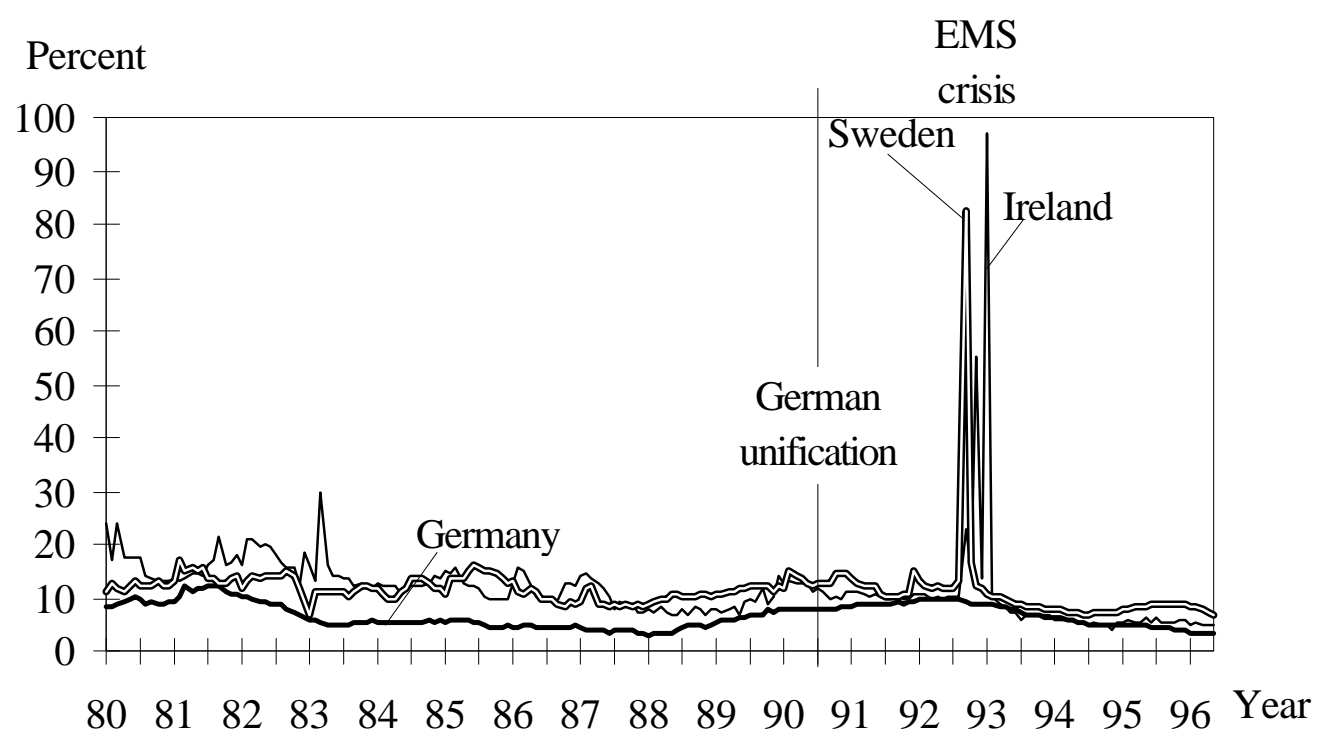

Sources: Bundesbank (various issues), Monatsbericht, Frankfurt/Main, Tables IV.4; letter from Bundesbank of July 11, 1996.

Notes: All rates are monthly averages of daily interest rates.

The crisis in the EMS culminated on the "Black Wednesday", September 16th, 1992. On that day, the membership of the British pound in the EMS was temporarily suspended, and the lira followed the next day. A period of successive devaluations of various currencies against the deutschmark began, and in the end both the UK and Italy were forced to leave the system. Sweden and Norway gave up their attempts to maintain a fixed exchange rate with the EMS currencies.

The successive devaluations added up to a substantial revaluation of the deutschmark. Figure 9 demonstrates the revaluation effect by comparing the trade-weighted exchange value of the deutschmark with its trade-weighted purchasing power parity (PPP) as measured by the OECD. The abscissa of the diagram shows the ratio of these two values. A value of one indicates an exchange rate equal to the OECD PPP. The data refer to 14 countries which together account for two thirds of Germany's foreign trade, ${ }^{10}$ and they include all countries that are, or were, members of the EMS. With regard to the EMS countries, the revaluation of the deutschmark between January 1992 and April 1995 was 20 percent in real terms. The respective revaluation figure for all countries which were considered was about $16 \%$.

\footnotetext{
${ }^{10}$ The rest is composed as follows: Developing countries including OPEC: $13 \%$; transition countries including China: $10.5 \%$; Switzerland $5 \%$; Others: $6.5 \%$.
} 
Figure 9: Real value of the deutschmark: 14 countries

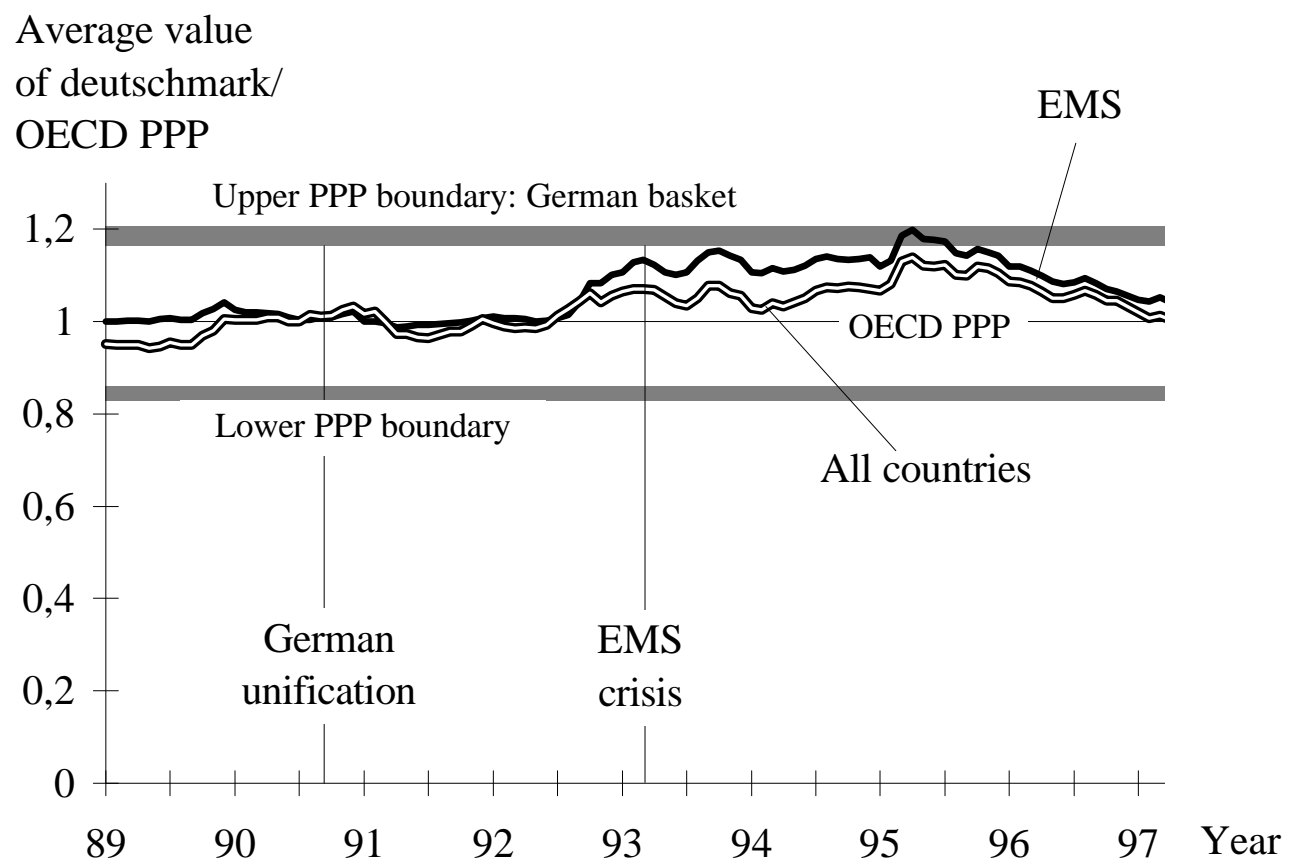

Sources: OECD, Main Economic Indicators, Paris 1996, p. 201; OECD, National Accounts, Paris 1996, Table 3, p. 158; Statistisches Bundesamt, Statistisches Jahrbuch für das Ausland, Wiesbaden 1995, Table 16.3, pp. 342-43; letter by Bundesbank of July 11 1996; Bundesbank, Monatsbericht, April 1989, Frankfurt/Main, p. 46; own calculations.

Notes: The EMS series is constructed as the weighted average of the ratio of exchange rates and OECD PPPs of EMS countries. Exchange rates are monthly and PPPs are annual data. Both indicate the value of a deutschmark; i.e. they use the respective foreign currency as the numeraire. Weights are based on 1989 trade flows following the external value concept of the Bundesbank. EMS countries include Austria, Belgium, Denmark, Spain, France, Italy, Ireland, Netherlands, Portugal, and the UK. "All countries" are EMS countries plus Finland, Sweden, Japan, and the US. A series takes the value 1 if the weighted average of the exchange rates equals the weighted average of the OECD PPPs. The higher limit of the upper boundary gives the weighted mean of the PPPs based on the German basket relative to the PPP according to the OECD basket for all countries. The lower limit of the upper boundary gives the respective PPP value for the EMS countries. As a rule, German basket PPPs are above OECD basket PPPs. The limits of the lower boundary are the inverse of the respective limits of the upper boundary.

These figures are significantly smaller than the respective figures for the revaluation of the dollar in the eighties, which in trade-weighted real terms was about $50 \%$, but they are nevertheless large if one takes into account the fact that the German economy is much more integrated into the world economy and is less self-sustaining than the US economy. In the eighties the export share in the US GDP was about $9 \%$ while Germany's current export share is $21.2 \%$. Even a $16 \%$ revaluation for the deutschmark is a dramatic amount which severely threatens the competitiveness of the German economy. In 1969 a furious debate about a revaluation by $8.5 \%$ preceded to the collapse of a German government.

\footnotetext{
${ }^{11}$ See Sinn (1988, p. 39) where a diagram with unpublished IMF data is shown.
} 


\section{Alternative Explanations of the Currency Crisis}

The unification shock seems an obvious explanation for the EMS crisis and the subsequent revaluation of the deutschmark. However, there are other explanations, and this section will briefly screen them.

A popular explanation favoured by many German politicians sees the revaluation of the deutschmark as a proof of Germany's strength, of the soundness of its economic policy, and of the confidence of international investors. ${ }^{12}$ This explanation is wishful thinking. It may describe the investors' expectations about what other investors believe, but it certainly does not describe the economic fundamentals underlying these expectations. German economic policy after unification has not been sound. It has failed to prevent the disastrous wage development, and with massive subsidies, of a size hitherto unknown in the history of industrialised nations, it has created nothing more than a straw fire in the east. The jump in the German debt ratio and the failure to satisfy the Maastricht criterion do not provide a basis for confidence in the strength of the German economy or in German economic policy.

If the interpretation advanced in this paper is correct, it was the weakness and not the strength of the German economy which created the currency crisis and the revaluation of the deutschmark. The high capital demand, particularly by the public sector, raised the German interest rates which, in turn, attracted foreign capital and thus induced the revaluation. With a less destructive policy for east Germany, the German resource demand, interest level, and exchange rate would all have been lower.

Another explanation for the revaluation often advanced in Germany refers to the apparently low German inflation rate. The excess of foreign inflation over German inflation, so the argument goes, built up a revaluation potential for the deutschmark and created the pressure which led to the breakdown of the EMS in $1992 .{ }^{13}$ This argument, too, is not convincing. Why it is not convincing becomes obvious by again inspecting Figure 9. The figure shows that, before the EMS crisis, the value of the deutschmark was approximately equal to

\footnotetext{
${ }^{12}$ According to the Bundesbank (Geschäftsbericht 1992, Frankfurt/Main, p. 82) the "true reason" for the breakdown of the EMS was the "...failure to correct the exchange rates according to the accumulating differences in the development of prices, costs, budget deficits, and current accounts." (own translation).

${ }^{13}$ See the quote above. For a similar line of reasoning compare Eichengreen and Wyplosz (1993, p. 64).
} 
the OECD PPP and there was no apparent tendency for this value to fall below the OECD PPP, which might perhaps have justified a revaluation. ${ }^{14}$

A major reason for why this was so is the "franc fort" policy of the French central bank which had, in fact, implied that, for some years, the French inflation rate was lower than the German one. Since France is Germany's most important trading partner, the franc fort policy explains a substantial part of the flat trend of the real exchange value of the deutschmark before the currency crisis.

Admittedly, the OECD PPP is not the only basis for making a judgement about a revaluation potential. The horizontal upper boundary in Figure 9 indicates the PPP value for the German consumption basket published by the Statistisches Bundesamt. Judged by the German basket PPP, there was indeed a revaluation potential which might explain the EMS crisis. However there are at least two counter arguments to this interpretation.

One is that in early 1995 the value of the deutschmark in terms of the EMS currencies went even beyond the German basket PPP value. This indicates an additional cause for a revaluation.

The other counter argument denies the validity of a PPP comparison based on only one country's currency basket. In general, the PPP value of a currency is high when it is calculated on the basis of that country's basket of commodities, since commodities which are cheap there have a high weight. This is simply a result of the relative price effect. If the lira is evaluated on the basis of the American consumption of gasoline, its purchasing power value is low, but so is the value of the dollar if it is evaluated on the basis of Italian wine consumption. Thus, if the baskets of other countries are chosen, then, in general, a rather low PPP value of the deutschmark should be found. The statistical information about the UK and Sweden, which is reported in Figure 11 below, confirms this. Thus a comparison based on the OECD basket

\footnotetext{
${ }^{14}$ Even if the exchange rate had fallen relative to the PPP, this would not necessarily have indicated a revaluation potential because it could simply have resulted from the Balassa effect. With the integration of poor east Germans in the German economy the price level of non-traded goods has fallen and hence an appropriately calculated PPP value should have risen after unification which is the same as saying that the exchange rate should have fallen relative to the OECD PPP. The fact that this obviously was not the case (Figure 9) strengthens the argument put forward in this paper that the deutschmark was not undervalued before the crisis.
} 
which is an average of the respective country baskets seems best suited for a judgement, and this comparison lends no support for the "undervaluation thesis". ${ }^{15}$

Figure 10: Did the Bundesbank cause the EMS crisis?

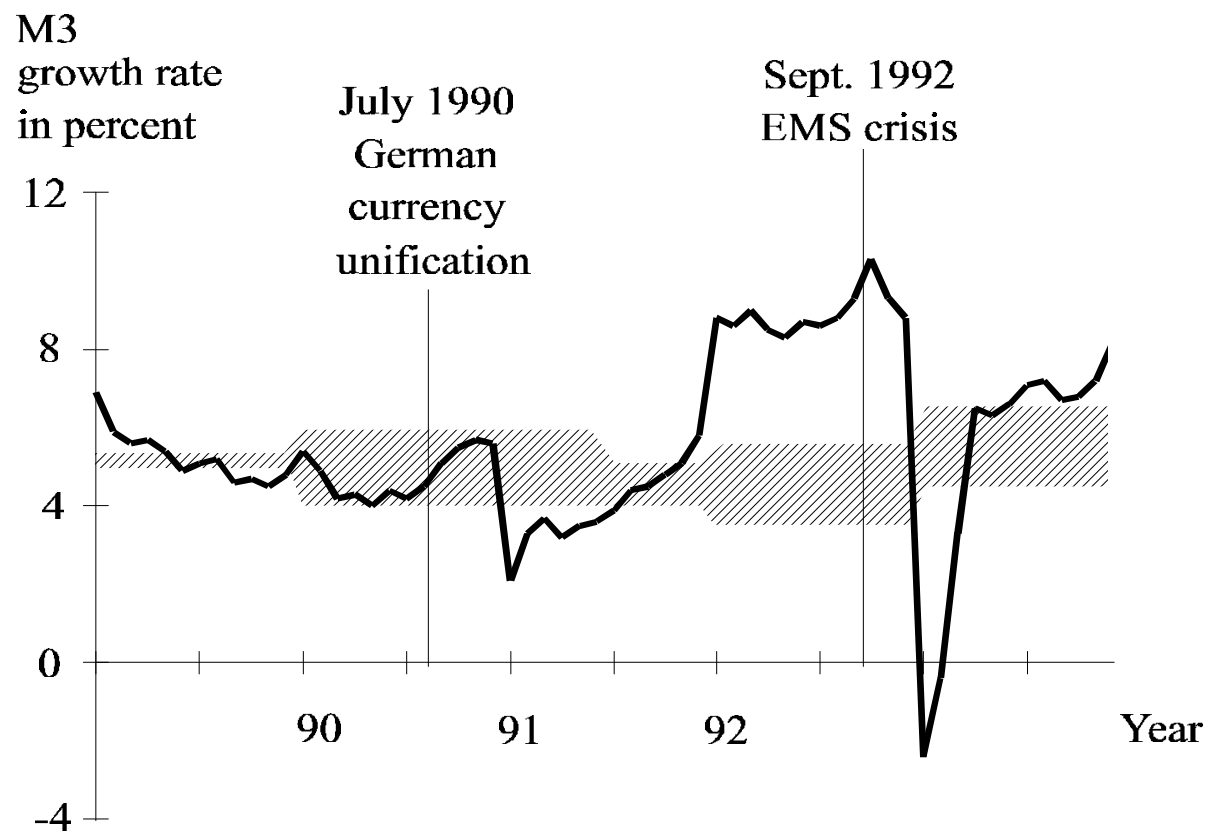

Sources: Bundesbank, Geschäftsbericht 1995, Frankfurt/Main, p. 79; Bundesbank, Saisonbereinigte Wirtschaftszahlen - Beihefte zum Monatsbericht, April 1993,1995, Frankfurt/Main, Table I.1, p. 6.

Notes: The growth targets are announced by the Bundesbank on an annual basis. After 1990, a growth zone instead a single target rate was announced. The target variable is M3. Following the Bundesbank's methodology, the actual growth rates are monthly changes of M3 as compared to the average stock in the last quarter of the previous year translated into annualised rates.

A third explanation for the EMS crisis that competes with the one given here refers to the Bundesbank's monetary policy at the time before the crisis. ${ }^{16}$ The Bundesbank has been severely criticised for carrying out a too restrictive monetary policy before Black Wednesday. The argument was that it had put German price stability above the survival of the EMS and had artificially created the demand for deutschmarks in the foreign exchange markets by reducing the money supply and boosting German interest rates. This argument reflects the anger of the other central banks when faced with the floods of capital leaving their countries, but it is false. Figure 10 shows that the Bundesbank did not carry out a contractionary policy,

\footnotetext{
${ }^{15}$ Unfortunately, only the information about the PPPs based on the OECD and German baskets is available for all countries. So the lower PPP boundary which would result from using Germany's trading partners' baskets is unknown. However, in a symmetrical situation, its relative distance to the OECD PPP should be the same as that of the PPP based on the German basket. The "lower PPP boundary" illustrated in Figure 9 reflects this assumption.

${ }^{16}$ See De Grauwe (1994, p.152).
} 
on the contrary, it tried to provide liquidity to the German banking system so as to keep the German interest rates down.

From the end of 1991 and right through the crisis, the actual growth rate of M3 exceeded the target zones which the Bundesbank had originally announced by more than 4 percentage points, and only after the crisis in late spring 1993 did the Bundesbank make an attempt to correct the excessive money growth. To read anything into Figure 10 that could be interpreted as a criticism of the Bundesbank would be courageous, to say the least.

The only alternative explanation for the EMS crisis which, in the author's opinion, merits attention is the speculative attack theory that Eichengreen and Wyplosz (1993) applied. According to this theory, pegged exchange rates like those in the EMS invite speculative attacks by investors because there is nothing to lose if the attack fails but much to gain if it succeeds. Pegged exchange rates are inherently unstable. The incentive to buy a currency is higher the greater the number of speculators who have already made the decision to buy, because the more people buy, the larger the probability that the central banks will be unable to defend the exchange rate.

While the theory is an important part of the mosaic that gives a picture of what has happened, it cannot explain why a speculative attack begins and the direction such an attack takes. It is a theory that explains the amplification of an existing shock and nothing more. The view that the unification of Germany caused the currency crisis harmonises very well with this theory.

\section{Implications for the Maastricht Treaty}

On January 1, 1999, the Bundesbank will have lost its sovereignty and the deutschmark will no longer be a separate currency - it will only be a sub-unit of the Euro just as a penny is the subunit of the deutschmark. By the end of 2001, deutschmark coins and bank notes will have disappeared. The destiny of the other currencies joining the EMS will be similar, but these currencies will only be known in 1998. Definitely France, Austria, the Netherlands and Luxembourg will be members. The rest is unclear. However, in all likelihood Germany and France will not be able to exclude many other countries which violate the Maastricht criteria 
even if they wanted to, because they themselves do not satisfy those criteria. In nearly all cases, it will be necessary to stretch article $104 \mathrm{c}$ of the Treaty of Maastricht to make a membership possible.

The problem with the treaty is that Germany's unification shock will not have been fully absorbed when the exchange rates are irrevocably fixed in 1998. Thus the exchange rates will be frozen at a level which is appropriate for the current need to pump economic resources into Germany, but this level will not be appropriate in the future when there is no need for the injection of further resources or when Germany cannot afford such an injection any longer. ${ }^{17}$ The future adjustment of the exchange rates can only occur in real terms through diverging inflation rates, if not diverging deflation rates. If the European Central Bank behaves as the treaty of Maastricht demands, it will try to satisfy the goal of price stability above and before all other goals. If it succeeds on average, Germany will have to deflate to allow its real exchange rate to come down again.

However, a deflation is a painful process. House owners and firms will see the real value of their debt increase, because they did not anticipate the deflation and because they cannot change existing debt contracts. The German real wages, which are already too high, will increase further. There will be waves of bankruptcies and forced sales of rental and owner occupied houses, leading to a rapid devaluation of existing assets. The EMS crisis will be followed by a German crisis.

The potential dangers seem particularly apparent if it is realised that the accumulation of foreign debt with which Germany is currently financing its transfers to the east results in an increase in the flow of interest payments to (or reduced flow from) foreigners. This increase will have to be financed in the long run with a trade surplus which in turn requires an undervaluation; i.e., even lower commodity prices and even more deflation. The longer the current period of resource inflows into Germany lasts, the lower the German price level will have to be in the long run in order to service the debt. ${ }^{18}$

\footnotetext{
${ }^{17} \mathrm{An}$ economic model that predicts the rise and fall of the deutschmark value is provided by Adams, Alexander and Gagnon (1993). However, due to its Ricardian nature, this model abstracts fully from the effects of the increased public deficit which explains more than two thirds of east Germany's excess absorption. Cf. Figure 1.

${ }^{18}$ Wyplosz (1991) had used a similar kind of argument to demonstrate that German unification would result in a depreciation of the deutschmark right from the beginning. National investors, so his argument went, would know the long run equilibrium of the exchange rate and would therefore anticipate this value in today's
} 
If the European Central Bank is less concerned about the issue of price stability, the problem for Germany becomes less severe. The necessary adjustment of relative prices can be accomplished with diverging inflation rates alone. However, the problem now will be the inflation in other European countries. The expected monetary stability will not result from the Maastricht treaty. European monetary policy will be between Scylla and Charybdis. It is impossible to avoid both a deflation in Germany and an inflation in other countries.

Unless, there is another realignment before the monetary union begins. At first sight, it might appear that this realignment could best be achieved by a unilateral devaluation of the deutschmark. However, this is not advisable because, since 1992, only some currencies have been devalued relative to the deutschmark. The French and Belgian francs, the guilder, the Danish krone and the Austrian schilling have not been devalued. They would become overvalued if the deutschmark were devalued. The only way to resolve the dilemma (apart from the dangerous strategy of postponing the currency union) seems to revalue those currencies that are obviously undervalued at present.

To decide which currencies will need a realignment it seems useful to compare the exchange rates of the single currencies with the respective PPP values. Such a comparison is made in Figure 11. For each of the 14 countries considered in this study, Figure 11 indicates the time paths of the exchange rate, the OECD PPP, the PPP according to the German basket and, if available, the PPP based on the respective foreign basket. 
FIGURE 11 (not displayed in PDF version) 
There is no problem with Austria and Belgium. The exchange rates have been stable and lie in the neighbourhood of either the German PPP or the OECD PPP, which are anyway close to one another.

The Danish exchange rate has been stable, but is below the German and OECD PPPs. The krone seems to be slightly overvalued.

The Finnish markka was strongly overvalued before the EMS crisis. After some initial overshooting of the exchange rate the value is now in the neighbourhood of the OECD PPP.

The Irish exchange rate seemed correct before the EMS crisis, but now the Irish pound seems strongly undervalued. The exchange rate of the pound is not only below the OECD PPP, but even below the German PPP. A revaluation of the Irish pound may be worth considering before Ireland enters the currency union.

This is similar with the lira. The lira was strongly devalued during the currency crisis and even more so in 1995 when a political crisis was added. In order to satisfy the German PPP, the deutschmark would have to cost about 880 lire, and in order to satisfy the OECD PPP only 750 lire. In fact however, it costs about 1000 lire. Until the undervaluation of the lira is corrected, the lira will have difficulties participating in the currency union.

France and the Netherlands create no problems whatsoever. Both exchange rates have been stable and both have been close to the PPPs. If anything, the franc is slightly undervalued. However, the margins are so small that it is clear that France and the Netherlands can safely join a currency union.

This may not be so for Portugal and Spain. The escudo was undervalued both before and after the currency crisis. Only during the crisis was its value within the PPP bounds. The peseta was within the bounds before the crisis, but after the crisis its value collapsed like that of the Italian lira. While the escudo's chronic undervaluation may partly be attributed to the Balassa effect, the values of the peseta and the lira deviate too much for such an explanation to make sense. After all, the two countries are well developed. There rather seems to be an idiosyncratic Mediterranean deviation from the PPPs which makes it more than doubtful whether these currencies can be integrated into the currency union without a substantial revaluation. 
The Swedish picture is reminiscent of the Finnish one: before the crisis the krone was overvalued, but now the value seems right, it approximates the OECD PPP and it currently just equals the Swedish-basket PPP (one of the few country specific PPPs available).

A major problem is the UK, and even a Major may not be able to master it. Relative to the British, German, and OECD PPPs the British pound is currently strongly undervalued. The deutschmark costs about 43 pence but it should at most cost 37 pence, the German PPP. If Britain joins its current exchange rate it would spoil the party and create the kinds of problems described above.

To summarise this section, it seems that the currencies of Austria, Belgium, Denmark, Finland, France the Netherlands, and Sweden are roughly correctly valued by the markets. The Irish pound and the Portuguese escudo are undervalued, and this is a fortiori true for the lira, the peseta and the British pound.

\section{The German Currency Union as a Warning for Europe?}

Karl Otto Pöhl, the former president of the Bundesbank, warned the European Parliament not to agree to a currency union since this would be a "disaster" as, in his opinion, the German currency union was. ${ }^{19}$ Pöhl was right about the German currency union, but wrong about the European one. The similarity between the two currency unions is very limited.

A major reason why the German currency union turned out to be disastrous for the east German industry was that it was combined with a real revaluation of the east German price level by $340 \%$. Because all prices and wages were fixed in numerical terms (while debt contracts were cut in half), east German products became 4.4 times as expensive for west German buyers than before the currency union.

Before unification a big hole in the iron curtain always existed for the purpose of active intra-German trade. This trade took place at special prices which were equivalent to an exchange rate between Ostmarks (east) and deutschmarks (west) of 4.3:1. The east German economy had been competitive at this rate, delivering many commodities to the west German

\footnotetext{
${ }^{19}$ In a speech delivered to the economic and monetary section of the European Parliament on January 7, 1991.
} 
market through west Germany's trade chains. The currency unification had simply equated one Ostmark to one deutschmark, thus destroying east Germany's competitiveness over night.

The currency union not only destroyed the east German industry, it also turned out to be a major obstacle to a subsequent recovery because it paved the way for additional wage increases. The unification had made it possible for west German trade unions and west German employers' associations to open offices in the east and to negotiate east German wages. Since both parties were more interested in the safety of west German work places than a quick recovery of the east German industry, they were happy to agree to overly generous wage contracts for their east German competitors which implied a full equalisation of union wages by 1996. The currency union and the subsequent proxy negotiations for east German firms have had the joint effect of a tenfold increase in east German wages in terms of deutschmarks. East German wages used to be $7 \%$ of west German wages (in terms of deutschmarks), now they are about $70 \%$. They would even be higher if many east German firms and workers had not in the meantime rejected the wage decree of their western colleagues, as indeed they have.

Fortunately, none of these effects will endanger a European currency union. If only those seven countries identified in the last section join, there will be no risk whatsoever. The exchange rates have been stable for a long time and they will be fixed in 1998 at exactly the level they had. The revaluation effect which destroyed the east German industry is missing. There will be no problems either if Ireland and Portugal join after a realignment that brings these countries closer to their PPPs. Pöhl was wrong when he equated the two currency unions.

This is also true with regard to the successive wage negotiations which were so problematic in Germany. There is no way German trade unions could enforce their wages on Portuguese workers after a European currency union is created. Each country retains its own sovereignty. Proxy negotiations of the German type are unthinkable in the European context. 


\section{Conclusions}

The German unification shock has created substantial difficulties for Germany's trading partners and has triggered off the crisis of the EMS. A number of currencies are currently undervalued relative to a long run equilibrium which presumably lies in the neighbourhood of PPP values.

In the light of these difficulties, the timing of the European currency union may not be optimal. A priori, it might have been better to wait another couple of years. However, it is a matter of fact that the union has been agreed to in the Maastricht treaty and that it has been ratified by 15 European parliaments. Stopping the process now would damage the unification process of Europe. The paper has identified the countries which could join without problems and the precautionary measures which could be taken for others whose exchange rates are still out of line. If these rules are taken, the German and European unifications will harmonise well with one another. 
References

Adams, G., L. Alexander and J. Gagnon, "German Unification and the European Monetary System: A Quantitative Analysis," Journal of Policy Modelling 15, pp. 353-392.

Branson, W. (1993): "Comment" [on Eichengreen and Wyplosz (1993)], Brookings Papers on Economic Activity, 1/1993, pp. 125-139.

---, (1994): "Comments" [on Rose and Svensson, European exchange rate credibility before the fall, same issue], European Economic Review 38, pp. 1217-1220.

De Grauwe, Paul (1994), "Towards EMU without the EMS", Economic Policy 18, pp. 147185

Eichengreen, B.J., and Ch. Wyplosz (1993): "The Unstable EMS," Brookings Papers on Economic Activity, 1/1993, pp. 51 - 143.

Issing, O. (1992): "The Impact of German Unification on the Members of the European Community," in: Deutsche Bundesbank, ed., Auszüge aus Presseartikeln 75, pp. 3-6.

Sinn, G., and H.-W. Sinn (1992), Kaltstart, Volkswirtschaftliche Aspekte der deutschen Vereinigung, 2nd edition, Mohr:Tübingen (First German edition 1991, first English edition: Jumpstart. Economic Aspects of German Unification, MIT Press: Cambridge, Mass. 1993.)

Sinn, H.-W. (1984): "Die Bedeutung des Accelerated Cost Recovery System für den internationalen Kapitalverkehr," Kyklos 37, pp. 542-576.

---, (1988): "United States Reform 1981 and 1986: Impact on International Capital Markets and Capital Flows," National Tax Journal 41, pp. 327-340.

---, (1993), "American Economic Policy and the International Debt Crisis", Journal of International and Comparative Economics 2, pp. 207-226.

Sinn, H.-W., and A.J. Weichenrieder (1996): "Foreign Direct Investment, Political Resentment and the Privatization Process in Eastern Europe," Unpublished Discussion Paper prepared for the Conference on Policy Studies to Promote Private Sector Development, European Bank for Reconstruction and Development, London 26-27 April, 1996. 
Svensson, L. (1994): "Fixed Exchange Rates as a Means to Price Stability: What Have we Learned?" European Economic Review 38, pp. 447-468.

Wyplosz, Ch. (1991): "On the Real Exchange Rate Effect of German Unification", Weltwirtschaftliches Archiv 127, pp. 1-17. 